\title{
Promoting Gender Equality in EU Development Aid: From Transformative Policy to Transformative Practice?
}

\section{By Petra Debusscher}

The European Commission combines specific funds for women's empowerment with gender mainstreaming in its twin-track approach to gender equality in development aid policies. This strategy is only partially successful as it fails to address the needs of the poorest developing countries, privileging instead EU interests. The gender mainstreaming approach lacks transformative potential and it is characterised by expert-bureaucratic concerns

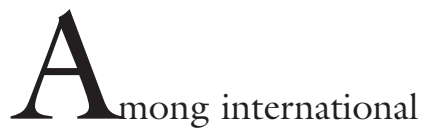

organisations the European Union (EU) stands out in its support for gender equality. The Lisbon Treaty considers "equality between women and men" among its values and objectives, and since 1996, the EU has committed to integrate gender considerations into all aspects of its operations and policies. The Union (Commission and member states) is also the world's largest development aid donor, providing 55 percent of official development assistance globally. But to what extent has this been used to advance gender equality goals? Has the EU promoted gender equality in its development policies in a transformative way? Or has the approach towards gender equality in its foreign aid remained rather 'mainstream'? This article examines the gender perspective in European Commission (EC) development aid by critically investigating its twin-track strategy. After elaborating on gender equality policies in the EU and in its development policies I delve into the 
analysis of the financing of measures which directly support women's empowerment. Next I analyse formal and substantial aspects of gender mainstreaming in EC development aid. The paper concludes that only part of the twin-track strategy is travelling well within EC bureaucracies and that gender policies in EC development policy are realized in a limited, interestguided and expert-bureaucratic manner. Such an approach severely limits the transformative potential of the twin-track strategy.

\section{GENDER EQUALITY POLICIES IN THE EU}

The historical evolution of EU gender equality policies can be characterized idealtypically as a three-phased evolution, starting with equal treatment in the seventies, over positive action in the eighties to gender mainstreaming in the nineties (Rees 1998; 2002). The equal treatment approach "implies that no individual should have fewer rights or opportunities than any other" and implies a "legal redress to treat men and women the same" (Rees 1998: 29; 2002: 46). The approach is embodied in the adoption of article 119 and the following series of Directives on equal pay and equal treatment in the workplace. Equal treatment is essentially flawed because equality of access does not lead automatically to equality of outcome; fails to address fundamental causes of inequality and wants to include excluded women in the world as it is without undermining the underlying male norm and dominant patriarchal values (Rees 1998). It is also only focused on women's formal rights as workers (Pollack \& Hafner-Burton 2000).

Positive action shifts the goal from equality of access to equality of outcome by creating the conditions that will more likely result in equalizing starting positions (Rees 1998: 34). The positive actions approach recognizes differences between men and women and problematizes the unquestioned male norm. This approach involves specific measures on behalf of women, for example quota or vocational training for women re-entering the job market. In the European context positive action measures are embodied in a series of Action Programmes, which fostered pilot projects and best practices exchange in areas like child care or political representation of women, as well as the creation of expert and advocacy networks for women's rights (Pollack \& Hafner-Burton 2000). Yet, as in equal treatment the approach is concerned with the distribution of positions within hierarchies, rather than challenging the structural gender status quo (Rees 1998).

By contrast, in the gender mainstreaming approach - linked with the concept of transformation - it is the gendered world itself that is problematic and "not only the exclusion of women or the existence of a male norm" (Verloo \& Lombardo 2007: 23). Gender mainstreaming should then ideally involve analysis of how current systems benefit men or cause indirect discrimination in order to redesign these systems and structures (Rees 2002). Because the gender mainstreaming approach takes a system approach it is believed to have a "more transformative potential than previous equality policies" (Squires 2005: 370). Gender mainstreaming thus enables us to transcend the classical Wollstonecraft dilemma, because it goes beyond the opposition between equality of opportunity and equality of outcome, as embodied by equal treatment and positive action and "focuses on the structural reproduction of gender inequality and aims to transform policy processes such that gender bias is eliminated" (Squires 2005: 370).

Feminist literature on gender equality policies further distinguishes between "integrationist" and "agenda-setting" models, as established by gender and development scholar Rounaq Jahan (1995: 126-127). An integrationist model addresses "gender 
issues within existing ... policy paradigms" (Beveridge \& Nott 2002: 300), whereas an agenda-setting model aspires "to transform the ... agenda" on many fronts ("in decision-making structures and processes, in articulation of objectives, in prioritization of strategies, in the positioning of gender issues amidst competing emerging concerns, and in building a mass base of support among both men and women"). This transformation will require "giving primacy to woman's agency" and "strengthening women's groups and organisations." (Jahan 1995: 126-127). Another well-established classification is Beveridge and Nott's distinction between "expert/bureaucratic" and "participatory/democratic" responses to gender mainstreaming. Expert/bureaucratic models towards gender mainstreaming "focus on the use of experts and/or the establishment of mainstream "routines" within state bureaucracies", while participatory/democratic approaches "emphasise the inclusion or empowerment of disadvantaged groups in relation to policy-making" (Beveridge \& Nott 2002: 301). Judith Squires argues that Jahan's integrationist and agenda-setting models intersect with Beveridge and Nott's expert/bureaucratic and participatory/democratic models and argues that a participatory/democratic or agenda-setting response towards mainstreaming is correlated with a transformative agenda. Involving women's voices in the policy process is thus linked with a transformative outcome (Jahan 1995, Squires 2007). In the next section I elaborate briefly on the evolution of integrating gender equality objectives in EU development policy.

\section{GENDER EQUALITY IN EU DEVELOPMENT POLICY}

The first attempts to integrate gender equality in EU development policy took place in the context of the United Nations (UN) Decade for Women 1975-1985 and the Third World Conference on Women in Nairobi in 1985. Following these events the European Commission (EC) established its 'Women in Development' (WID) policy, including its first WID desks, communiqués and references to women in the Third and Fourth Lomé conventions (1984 and 1989) (Peto \& Manners 2006). This WID perspective addressed the exclusion of women from the development process by creating specific projects for women. Increasingly the WID paradigm was criticized by feminist scholars pointing out that focussing on women in isolation is ineffective as it ignores the underlying societal problem, namely unequal gender relations (Moser 1993). Following the 1995 UN Beijing Conference on Women - in which the EU played a key role in drafting the Beijing Platform of Action - the WID paradigm was set aside by the international community and replaced by the 'Gender and Development' (GAD) paradigm and the strategy of gender mainstreaming that implements it. The innovative element of GAD and gender mainstreaming is that it widens the scope from add-on, small-scale projects focussing on women, to the integration of a gender equality perspective into all policies in an effort to transform society and obtain social justice for all people. Where WID policies - even those policies aimed at redressing the imbalances between the sexes - were directed at women only, the gender mainstreaming approach stresses "the shared responsibility of women and men in removing imbalances in society" (Council of Europe 1998: 18). As the ultimate aim of gender mainstreaming is to change discriminatory gender norms, structures and practices in society, it is regarded as a transformative approach.

Since the UN Beijing Conference in 1995 the EU has made high-level political commitments to mainstreaming gender in its development policy. In a ground-breaking resolution of late 1995 the EU Council of Ministers first declared the integration of 
a gender perspective in development co-operation as a crucial principle underpinning the development policy of the Community and the Member States (European Council 1995). This was followed by a string of high-level policy documents on integrating gender equality in development, including a 1998 Regulation on Integrating Gender Issues in Development Co-operation (European Council 1998). In 2001 the Commission published its Programme of Action for the Mainstreaming of Gender Equality in Community Development Cooperation which stipulates a twin-track strategy to achieve gender equality. Such twin-track strategy implies that "the EC is committed to including gender equality goals in the mainstream of EC development co-operation policies, programmes and projects" (gender mainstreaming), while "concrete actions targeting women (specific actions)" reinforce these processes (European Commission 2001: 8-13). More recently, the EU has adopted high-level policy documents which update the earlier arrangements and reconfirm the twin-track strategy towards gender equality (European Parliament and Council 2004, European Commission 2007a, 2010).

Guided by these significant political commitments to gender equality, the external services of the European Commission have institutionalized gender equality methodologies and principles across their policy and operational work. A lot has been achieved with respect to the development of gender equality norms and their adoption in EU political commitments to promoting a gender perspective in external policy. The work of transnational advocacy networks that include gender specialists, development non-governmental organizations and grassroots movements dedicated to achieving gender equality or advancing women's rights has been crucial in this norm-creating process. In practice however, several difficulties remain. In what follows I delve into the problematic aspects of gender policies in EC development aid by analysing first the financing of specific measures which support women's empowerment and second the integration of gender equality in general EC development aid.

\section{THE FIRST TRACK: SPECIFIC MEASURES FOR THE EMPOWERMENT OF WOMEN ${ }^{1}$}

Looking at the financing of measures which directly support women's empowerment next to gender mainstreaming - sketches a problematical picture and hints at a lack of political will for gender equality. The thematic budget line for empowering women in development co-operation has always been relatively small when compared to other budget lines (Arts 2006). Until 2007 these specific projects were funded through a specific budget line, known as the Gender

Table 1: Gender budget line allocations and commitments 1998-2006 (in million euros)

$\begin{array}{lccccccccc} & 1998 & 1999 & 2000 & 2001 & 2002 & 2003 & 2004 & 2005 & 2006 \\ \text { Budget Available } & 5 & 3.3 & 1.4 & 2 & 2 & 2.5 & 2.9 & 2.8 & 2.8 \\ \text { Commitments } & \text { n.k. } & 3 & 1.4 & 1.7 & 2 & 2.5 & 2.9 & 2.8 & 2.8 \\ \text { Payments } & 3.2 & 1.2 & 1.7 & 1.9 & 0.9 & 2.3 & 1.3 & 1.6 & 2\end{array}$

Source: European Commission (2003a) and email exchange with AIDCO Unit F4 (May 2007). Example: In 2006, 2.8 million euros was made available and was committed for specific projects aimed at women's empowerment. However, only 2 million euros was actually spent. 
Budget Line. The 1998 Regulation provided its first legal basis and specified how the budget could be used to support gender mainstreaming in development co-operation, although the Gender Budget Line had existed prior to 1998. The available budget (the so-called committed credits) and the actual commitments and disbursements in the years 1998-2006 are presented in table 1 .

Prior to 1998, 5 million euros was made available annually (European Commission 2003). Since then, as table 1 shows, the Gender Budget Line and payments have greatly diminished, recovering only slightly between 2003 and 2006. Of further note is the difference between the annual budget, the amount committed to specific projects and contracts and the amount actually spent. Although the 1998 Regulation promised 25 million euros for the period 1999 to 2003 (i.e. five million euro annually), substantially less was actually committed. In programming, if not in policy, the budget was drastically reduced. Indeed, the 2003 EU Thematic Evaluation observed that the available financial resources were not fully being used to promote gender equality. Several factors had limited the use of resources for carrying out gender equality projects. The selection system and criteria for funding women's organisations were very strict and excluded smaller southern civil society groups because of the extensive policy requirements for the Gender Budget Line compared with other budget lines. Further insufficient infrastructure resources and staff capacity to disburse the limited funds for positive actions targeted at women in developing countries further hampered the allocation (European Commission 2003).

The financial outlook for specific measures for women's empowerment appears to be more supportive for the period 2007 to 2013. The EU budget for external relations has been overhauled with the number of budget lines and individual regulations being trimmed down. The Gender Budget Line has been replaced by a major chapter in Investing in People (European Commission 2006), which integrates all human and social development issues - culture, employment and social cohesion, children and youth, skills and knowledge, health, and gender equality - in a single document. Crucially, the total amount dedicated to women-specific projects and gender equality has been significantly increased, if I compare the previous Gender Budget Line 1995-2006 with the new gender chapter in Investing in People 2007-2013. Whereas under the Gender Budget Line 1995-2006, amounts between two and five million euros (see table 1) were committed to women-specific projects, under Investing in People, a sum of 57 million euros has been committed to gender equality for the period 2007-2013. This is 8.14 million euros annually, representing for most years more than double the amount previously committed for projects for promoting women's empowerment (European Commission 2007b).

This renewed financial commitment to specific projects for the empowerment of women in developing countries addresses some of the fears of gender advocates that the 'simplification' of budgeting would result in a drastic decrease in the allocation for gender-specific projects. However, while the overall sum of development assistance for gender equality is greater, the global distribution of the money privileges EU interests over any principled normative commitment to development and the needs of developing countries. Thus, 32 million euros will go to the designated European Neighbourhood countries (56 percent or 4.57 million euros annually), while 25 million euros has been committed for the rest of the world (44 percent or 3.57 million euros annually) including the African, Caribbean, and Pacific countries which are among the poorest. In addition, it is important to note that the amount of 57 mil- 
lion euros that has been designated for specific projects for the empowerment of women is still relatively small, when compared to the total budget for Investing in People or to other chapters. The total budget that was made available under Investing in People is 1,017.6 million euros, which means that only five percent is specified for specific projects for the empowerment of women. By contrast 587.6 million euros or 55 percent of the Investing in People budget is committed to the chapter "Good health for all" (European Commission 2007b).

The above section has made clear that, although the EU has made high level commitments to the empowerment of women in its development policy, problems remain in practice. In the next section I will take a closer look at how gender is mainstreamed in the EC's overall development policy.

\section{THE SECOND TRACK:}

\section{MAINSTREAMING GENDER IN EU DEVELOPMENT POLICIES}

Past EC reviews of gender mainstreaming in development aid have revealed that gender was weakly incorporated or even almost absent in the development programming documents (European Commission 2002a). Development non-governmental organization Aprodev stated that if the concept of gender and mainstreaming of gender equality was incorporated in the analytical part of the programming documents, it was not translated into the priority actions with matching budgets and performance indicators. If gender was addressed, it was thus mainly found in the diagnosis of the policy problem, but not in the implementing part (Sohet \& Ulmer 2002). For example, in the EC development programming document for Argentina the link between gender and poverty was illustrated with excellent data on women's salaries, income per hour, and the poverty ratio of female headed households.
However, this analysis on the feminization of poverty was the end point, and no concrete measures were outlined in the implementing part of the programming document (European Commission 2002b). Furthermore a 2003 thematic evaluation on the integration of gender in EC development co-operation with third countries confirms this gender gap between the analytical and implementing parts of programming documents stating that references to gender are primarily found in the analysis or policy background sections, and that "these references are very rarely translated into a strategy." The report adds to this that if gender is translated into a strategy with a budget and performance indicators, this is mostly in soft sectors like education and health (European Commission 2003: v).

In my dissertation research I have examined gender mainstreaming in EC development policy by quantitatively and qualitatively analysing Country Strategy Papers and National Indicative Programmes (from the period 2002 to 2006 and from 2007 to 2013) for 49 development countries ${ }^{2}$ (See Debusscher 2010a; 2010b; 2011). Country Strategy Papers ${ }^{3}$ and National Indicative Programmes 4 are bilateral agreements between the EC and the government of the partner country and are the main instruments for programming EC development aid. Given their importance in planning and implementing EC aid, the programming documents are regarded as the main "building blocks" to effectively gender mainstream policies in development practice (Painter \& Ulmer 2002: 4). The next two subsections consist of a quantitative and a qualitative analysis of formal and substantial aspects of gender mainstreaming in EC development programming documents.

\section{Analysis of formal aspects}

In the quantitative analysis of the programming documents I have counted references 
that relate exclusively to men and references that relate exclusively to women, 5 as a first step to examine the formal appearance of a language where men and women are both included. I have learned from this formal language analysis that there is a significant overrepresentation of references that relate exclusively to women: 56 percent of all gender specific references refer exclusively to women compared to 13 percent of gender specific references that relate exclusively to men. ${ }^{6}$ The language used in the EC programming documents is thus more the typical WID language that focuses on women, than a genuine GAD or gender mainstreaming language that involves both men and women in the analysis and solutions for gender equality.

Next I have analysed the claim from previous reviews that gender equality was incorporated mainly in the analytical parts of the programming documents, but not in the implementing parts. By analysing the distribution of gender issues in programming documents, I have learned that although gender issues are mostly integrated in the descriptive and analytical parts, gender issues are fairly well distributed in the strategic action-oriented parts as well. The claim in the thematic evaluation on gender issues in EC development cooperation that "[gender] references are primary found in the analysis or policy background sections of the CSP, and are very rarely translated into any strategy" (European Commission 2003: v) is no longer valid, especially for the second generation programming documents. In general EC development programming documents contain a gender analysis and an implementation strategy that addresses gender issues.

The third cut for the quantitative analysis was provided by examining the development budget and estimating what part of the total development budget was gender mainstreamed. The budget analysis shows that in the newest generation programming documents, gender issues are included into large part of EC aid (about 62 percent of the screened budget for 2007-2013). ${ }^{7} \mathrm{Up}$ to 27 percent of the total reviewed budget for 2007-2013 is even fully gender mainstreamed using gender indicators. For example in the Honduran National Indicative Programme, the following gender indicators have been outlined under the sector "Improving the Management of Natural Resources": percentage of land tenure regularised, of which percentage benefiting indigenous groups and women; percentage of participation by women in forestry programmes; number of jobs created through forestry investment, including number of people belonging to indigenous groups and number of women (European Commission 2007c: 41). The importance of gender indicators in the gender mainstreaming process has been widely recognised by the international donor community and the EU, which has also made high-level commitments to the use and development of gender indicators in its development aid (European Commission 2007a). Since gender indicators constitute a critical link between policy aspirations and policy practice (Walby 2005), I regard the use of such indicators as the most definite formal sign available in the programming phase of being fully gender mainstreamed. At least from a budgetary perspective, it seems that gender is mainstreamed well into the programming phase of EC development aid. The language, material format and budget are however only first steps in examining gender mainstreaming in EC development aid. They indicate at least a momentum and the will to dedicate money and attention to gender equality, which is a basic prerequisite for a policy with transformative potential. However, to assess if the approach is a transformative one we need to look at more substantial aspects of gender mainstreaming: the policy's content, the attained gender roles, and if women's voices are involved in policymaking. 


\section{Analysis of substantial aspects}

Investigating the EC programming documents qualitatively by looking at substantial aspects of gender mainstreaming does not draw the same pretty picture. Deeper analysis reveals that most of the time gender is only selectively mainstreamed in typical sectors linked to the empowerment of women, such as maternal health and primary education. Less obvious sectors, such as transport, trade or agriculture are rarely gender mainstreamed. The most frequently mentioned solutions for gender equality mentioned in the programming documents were access to education (found in $30 \mathrm{doc}-$ uments), employment (24), and reducing maternal mortality (13). The EC's development policies that are gender mainstreamed are thus mainly focussed on attaining the UN Millennium Development Goals ${ }^{8}$ or on integrating women in the job-market. Also gender equality in employment is often framed as a solution to eradicate poverty. For example in the Ethiopian Country Strategy Paper it is stated that "women's contribution to household income and production is crucial for fighting poverty." (European Commission 2002c: 11) In this case gender equality is not framed as a goal in itself, but used instrumentally to reach the goal of poverty eradication. In this poverty-frame the integration of gender equality in employment is also located within the Millennium Development Goals, namely goal one to eradicate extreme poverty. Notwithstanding the relevance of the Millennium Development Goals, women's organisations criticize them for their narrow scope and minimal agenda. In their view, the Millennium Development Goals ignore systemic political and power issues concerning gender inequality and do not use a human rights framework, which depicts people as rights holders who can mobilise to demand realisation of their rights rather than as passive recipients of policies (Barton 2005).

Furthermore, it was apparent that gen- der equality is framed as a women's problem only, since it is mainly women who are mentioned when analysing gender inequalities. Most of the time, men are absent in the gender analysis, serving as a silent norm. When men are mentioned this is mostly in a general phrase referring to equality between men and women. What is more, women are not only seen as the main problem holders in the gender (in)equality question, they are also made solely responsible for the solution. Men are never the target group to address gender inequalities. With the single exception of the Indian $\mathrm{Na-}$ tional Indicative Programme, where increased efforts will be made for greater responsibility and participation of men in reproductive health (European Commission 2007d), not a single other National Indicative Programme mentions men explicitly as solution holders in the gender inequality question.

Lastly, I examined the involvement in the drafting process of EC development policy of civil society groups working on gender equality in the partner countries. The research showed that national and regional civil society groups working on gender equality are barely included in the drafting of EC aid. National and regional women's organisations are not given a legitimate voice in providing information on gender equality issues. The sources referred to when giving information on gender equality are predominantly UN, World Bank or government sources. Further I discovered a significant gap between the views of civil society and the views of the EC on gender issues. 9 Contrary to the EC approach, regional civil society working on gender issues views gender equality more in terms of a rights-based approach. For example, as in the EC programming documents, reproductive health is a major concern for civil society actors. The difference being that in the EC programming documents the focus is on maternal or reproductive health, where in civil society texts 
the focus is on sexual and reproductive rights. The EC uses a health frame where civil society uses a rights frame. One Asian women's organisation even explicitly demands that a language of "sexual 'rights' and reproductive "rights" is used and "not just health" and stresses the importance of separating "sexual autonomy rights from reproductive rights" (APWLD 2008: 46).

It was also apparent that civil society analyses were in general more system-critical aiming at "structural transformation" (AFF 2006: 6), discussing the gender effects of globalisation, trade liberalisation, climate change or environmental degradation. Further, civil society actors approach patriarchy explicitly as a changeable system over time and space and stress its interrelation with systems "of class, race, ethnic, religious and global-imperialism" (AFF 2006: 11). To give an indication of the difference in tone, the term 'patriarchal' or 'patriarchy' were mentioned six times in about 7000 pages of examined EC programming documents and appeared 140 times in about 1000 pages of examined civil society documents. Also civil society puts significantly more intellectual energy in discussing ways out of the "deeply rooted societal norms, attitudes and practices" (GBVPN 2008: 2) in a way that involves both women and men. Examples include new masculinity campaigns, promoting change of the workplace culture, providing adequate parental leaving schemes shared by both parents, and role model strategies through education on exemplary women's lives. Contrasting the EC's take on gender equality with the views of relevant civil society actors in developing regions revealed important silences in the policy documents and exposed that the EC's approach is neither context-sensitive, nor agenda-setting. The qualitative analysis thus shows that gender is mainstreamed selectively, focussing on women and certain sectors only and ignoring the voices of civil society.

\section{CONCLUSION}

I conclude that although part of the EC's twin-track strategy is successful (in terms of the budget and in terms of formal appearance) the strategy is far from reaching its transformative goal. The global distribution of specific EC funds for women's empowerment (first track) is unequal and seems to privilege EU interests over normative commitments to development and the needs of the poorest developing countries. Obviously such interest guided-approach severely limits the "catalytic role" and transformative potential of the specific funds (European Commission 2003: X). Furthermore, it seems that gender mainstreaming ( $\mathrm{sec}$ ond track) is implemented in a rather limited and integrationist manner. Although comparative analysis from 2002 and 2007 shows that gender issues are integrated in all phases of the programming cycle (analytical and strategic parts) and that large part of the development budget is gender mainstreamed, three significant problems remain, which severely hamper the transformative potential. Firstly, the EC's development policies that are gender mainstreamed are mainly focussed on attaining the Millennium Development Goals or on integrating women in the job-market. Gender equality is thus not framed as a goal in itself, but is used instrumentally to attain other goals, like poverty eradication or economic growth. Secondly, gender equality is framed as a women's responsibility only, since men are almost never explicitly addressed in the analysis nor as a target group to resolve gender inequalities. In this sense, the EC gender mainstreaming approach has more the features of the previous WID perspective. Lastly, regional civil society working on gender equality in the developing regions is not consulted enough by the Commission. What is more, analysis of civil society voices reveals, not only that there is a lack of participation in the programming phase of EC aid, but also that there is a wide breach between how the EC frames 
gender (in)equality and how regional civil society frames this. Not only is this lack of space for civil society voices harmful to empowerment, it is also harmful for the relevance of policies because the policymakers' view of problem and solution is limited by the institutional culture and its predetermined goals. Clearly this restricts the scope of policy making and of the allocation of resources (Beveridge \& Nott 2002).

It becomes clear that only part of the twin-track strategy is travelling well within EC bureaucracies and that gender policies in EC development aid are conceptualized in a limited and exclusively expert-bureaucratic way that ignores gender issues civil society puts forward as crucial in their countries or regions. More recently, the 2010 Staff Working Document EU Plan of Action on Gender Equality and Women's Empowerment in Development extended the twin-track strategy to a "three-pronged approach" consisting of gender mainstreaming, specific actions, and political and policy dialogue which aims to put gender equality more systematically on the agenda of the political dialogue with partner countries (European Commission 2010: 7). Although the commitment of the EC negotiators and the governments of the partner countries is indeed an important step forward to bring gender equality to the table, it remains an elite-focussed approach. Much more will have to be done to create a substantially transformative approach towards gender equality. Transformation requires changing deeply rooted norms, practices, and structures that are discriminating and demands significant intellectual energies to imagine a changed society and the ways forward. "Giving primacy to woman's agency" and to "strengthening women's groups and organisations" (Jahan 1995: 126-127) who have shown to be able of thinking of such creative solutions that involve both women and men will be crucial to attain this goal.

\section{Notes}

1. This section is based on Debusscher and True, 2009.

2. Cambodia, Laos, Philippines, Thailand, Vietnam, Bangladesh, Pakistan, Maldives, India, Mongolia, Botswana, Ethiopia, Gambia, Ghana, Lesotho, Namibia, Rwanda, Seychelles, Sierra Leone, Swaziland, Tanzania, Zambia, Bolivia, Brazil, Chile, Colombia, Costa Rica, Ecuador, El Salvador, Guatemala, Honduras, Mexico, Nicaragua, Panama, Paraguay, Peru, Uruguay, Venezuela, Armenia, Belarus, Georgia, Ukraine, Algeria, Egypt, Jordan, Lebanon, Morocco, Tunisia, and Syria. 3. A Country Strategy Paper contains four key chapters: a country analysis, the national strategy, an overview of co-operation and a response strategy. The country analysis sketches the current situation of a country through sub-chapters looking at different aspects (e.g. political, economic, social, trade, environmental aspects,...). The overview of national policies of the partner country outlines the government's development strategy. Next, the Country Strategy Paper gives an overview of the past and ongoing development aid of the EC and other donors. The response strategy establishes the development priorities to tackle the problems described in the country analysis.

4. The National Indicative Programme makes the priorities from the Country Strategy Paper's response strategy operational by outlining the concrete development actions and adding timetables, budgets, and measurement indicators.

5. Including women, woman, girl, mother, and female and men, man, boy, father, and male respectively.

6 . The remaining gender specific references refer to both sexes equally (eg. referenes to 'sex' and 'gender').

7. The sum of the reviewed NIP budget was 5,514.15 million euros for the period 2002-2006 and 8,731.4 million euros for the period 20072013. For the first generation NIPs up to 68.17 percent of this total budget was not gender mainstreamed at all. Gender was not mentioned once in the objectives or expected results of the budgetary sectors, so it is probable that this share of the budget was not gender mainstreamed. For $2007-$ 2013 , the share of the budget that is not gender mainstreamed in the programming phase drops about 30 percent points going from 68.17 to 38.22 percent. This breakthrough improvement demonstrates that gender equality is becoming increasingly more important in the budget and in the concrete programming phase. The percentage of the budget that includes gender as a one-sen- 
tence phrase without further specification has increased from 6.59 percent to 14.24 percent when comparing the two generations. This indicates that part of the improvement is probably only a cosmetic upgrade. For example, in the Nicaraguan NIP it is mentioned that a "brief analysis will be carried out for each of the following cross-cutting issues: gender, environment...", without making specific what this analysis entails and how it will be used in practice (European Commission 2007e: 28).

8. More specifically Millennium Goal two promotes universal primary education, goal three promotes gender equality and empowers women (with the concrete target to eliminate gender disparities in all levels of education by 2015) and goal five wants to improve maternal health (with the targets to reduce maternal mortality and achieve universal access to reproductive health).

9. In addition to analyzing EC programming documents I have analyzed the views of relevant civil society actors on gender equality to detect possible 'silences' in the CSPs and NIPs (what is not said), and to determine whether gender mainstreaming is implemented as an agenda-setting approach which gives "attention to the substantive objectives of the women's movement" (Jahan 1995: 127). These civil society organisations included the Asian Rural Women's Coalition, the Asian Pacific Resource and Research Centre for Women, the Asia Pacific Forum on Women, Law and Development, the Committee for Asian Women, United for Foreign Domestic Workers' Rights, CREA, the African Feminist Forum, the African Women's Development and Communication Network, Environnement et Développement du Tiers-Monde, Synergie Genre et Développement, Gender-Based Violence Prevention Network, the Solidarity for African Women's Rights Coalition, Comité Latinoamericano y del Caribe para la Defensa de los Derechos de la Mujer, Red Latinoamericana Mujer y Hábitat, Red de Mujeres Transformando la Economía, Red Feminista Latinoamericana y el Caribe contra la violencia Domestica y Sexual, Marcha Mundial de las Mujeres-AL, Consejo Latinoamericano de Ciencias Sociales, Agencia Latinoamericana de Información, Red Latinoamericana de Católicas por el Derecho a Decidir, CIDEM, Campaña 28 de Septiembre, Comisión Internacional de Derechos Humanos para Gays y Lesbianas - Programa para América Latina, Cotidiano Mujer, Flora Tristán, Red de Salud de las Mujeres Latinoamericanas y del Caribe, Rede Feminista de Saúde, Red Latinoamericana y Caribeña de Jóvenes por los Derechos Sexuales y los Dere- chos Reproductivos, REPEM-DAWN, Sos Corpo, the Association of Women of the Mediterranean Region, the Collective for Research and Training on Development - Action, the Euro-Mediterranean Human Rights Network, the KARAT Coalition, and the Network of East-West Women. (See Debusscher 2010a, b and 2011).

\section{LITERATURE}

- AFF (African Feminist Forum) (2006): Reclaiming our spaces. Executive Summary of the 1st African Feminist Forum, 15-19 November, Accra. - APWLD (Asia Pacific Forum on Women, Law and Development) (2008): Political Economy of Violence Against Women in Asia Pacific. Summary Report of the Asia Pacific NGO Consultation with the United Nations Special Rapporteur on Violence Against Women, Its Causes and Consequences, 1213 September, Manila.

- Arts, Karin (2006): Gender in ACP-EU Relations: The Cotonou Agreement, in: Marjorie Lister and Mauritzio Carbone (eds.): New Pathways in International Development: Gender and Civil Society in EU Policy, Ashgate, Aldershot.

- Barton, Carol (2005): Where to for women's movements and the MDGs?, in: Gender and Development, 2005/1.

- Beveridge, Fiona and Nott, Sue (2002): Mainstreaming: a case for optimism and cynicism, in: Feminist Legal Studies, 2002/3.

- Council of Europe (1998): Gender Mainstreaming. Conceptual Framework, Methodology and Presentation of Good Practices. Council of Europe, Strasbourg.

- Debusscher, Petra (2010a): Gender Mainstreaming in European Commission Development Policy. Dissertation submitted in fulfilment of the degree Doctor in EU Studies. Ghent University, Ghent. - Debusscher, Petra (2010b): Gender Mainstreaming in European Commission Development Policy in Asia: A Transformative Tool?, in: Asian Journal of Women's Studies 2010/3.

- Debusscher, Petra (2011): Mainstreaming Gender in European Commission Development Policy: Conservative Europeanness?, in: Women's Studies International Forum 2011/1.

- Debusscher, Petra and True, Jacqui (2009): Lobbying the EU for Gender-equal Development, in: Jan Orbie and Lisa Tortell (eds.): The European Union and the Social Dimension of Globalization. Routledge, Abingdon. 
- European Commission (2001): Programme of Action for the Mainstreaming of Gender Equality in Community Development Cooperation,

$\operatorname{COM}(2001) 295$.

- European Commission (2002a): Assessment of Country Strategy Papers with Reference to Gender, February.

- European Commission (2002b): Country Strategy Paper en National Indicative Programme 20022006 for Argentina.

- European Commission (2002c): Country Strategy Paper en National Indicative Programme 20022007 for Ethiopia.

- European Commission (2003): Thematic Evaluation of the Integration of Gender in EC Development Co-operation with Third Countries

(1995-2001), Report prepared by PARTICIP $\mathrm{GmbH}$ for the European Commission, March. - European Commission (2006): Investing in People. Communication on the Thematic Programme for Human and Social Development and the Financial Perspectives for 2007-2013 (COM/2006/0018 final).

- European Commission (2007a): Gender Equality and Women Empowerment in Development Cooperation, $\operatorname{COM}(2007) 100$.

- European Commission (2007b): Proposal for Allocation of Funding under Thematic Programme 'Investing in People' 2007-2013, Online document available at:

http://ec.europa.eu/development/icenter/repository/how_we_do_strategy_annexes_en.pdf

- European Commission (2007c): Country Strategy Papers en National Indicative Programmes 20072013 for Honduras.

- European Commission (2007d): Country Strategy Paper en National Indicative Programme 20072013 for India.

- European Commission (2007e): Country Strategy Paper en National Indicative Programme 20072013 for Nicaragua.

- European Commission (2010): EU Plan of Action on Gender Equality and Women's Empowerment in Development 2010-2015, SEC(2010) 265, 8 March.

- European Council (1995): Resolution on Integrating Gender Issues in Development Cooperation, 12847/95, 20 December.

- European Council (1998): Regulation on Integrating of Gender Issues in Development Cooperation, 2836/98, 22 December.

- European Parliament and Council (2004): Regulation on Promoting Gender Equality in Development Cooperation, 806/2004, 21 April.

- GBVN (Gender Based Violence Prevention Net- work) (2008): Perspectives on Prevention, $\mathrm{n}^{\mathrm{o}} 7$, April 2008, Kampala.

- Jahan, Rounaq (1995): The Elusive Agenda:

Mainstreaming Women in Development. Zed

Books, London.

- Moser, Caroline (1993): Gender Planning and Development: Theory, Practice and Training. Routledge, London.

- Painter, Genevieve and Ulmer, Karin (2002): Everywhere and Nowhere: Assessing Gender Mainstreaming in European Community Development Cooperation. One World Action and Aprodev, London and Brussels.

- Peto, Andrea and Manners, Ian (2006): The European Union and the Value of Gender Equality, in: Ian Manners and Sonia Lucarelli (eds.): Values and Principles in European Union Foreign Policy. Routledge, London.

- Pollack, Mark A. and Hafner-Burton, Emilie (2000): Mainstreaming Gender in the European Union, in: Journal of European Public Policy, 2000/3.

- Rees, Teresa (1998): Mainstreaming Equality in the European Union. Education, Training and Labour Market Policies. Routledge, London. - Rees, Teresa (2002): The Politics of 'Mainstreaming' Gender Equality, in: Esther Breitenbach, Alice Brown, Fiona Mackay and Janette Webb (eds.): The Changing Politics of Gender Equality in Britain. Palgrave, Basingstoke. - Sohet, Karine and Ulmer, Karin (2002): Rapid Survey of 40 ACP Country Support Strategies: What about Civil Society Participation? Aprodev, Brussels.

. Squires, Judith (2005): Is Mainstreaming Transformative? Theorizing Mainstreaming in the Context of Diversity and Deliberation, in: Social Politics: International Studies in Gender, State \& Society, 2005/3.

- Squires, Judith (2007): The New Politics of Gender Equality. Palgrave, Basingstoke.

- Verloo, Mieke and Lombardo, Emanuela (2007): Contested Gender Equality and Policy Variety in Europe: Introducing a Critical Frame Analysis Approach, in: Mieke Verloo (ed.): Multiple Meanings of Gender Equality. A Critical Frame Analysis of Gender Policies in Europe. Central European University Press, Budapest.

- Walby, Sylvia. (2005): Measuring Women's Progress in a Global Era, in: International Social Science Journal, 2005/2. 
SUMMARY

Promoting gender equality in EU development aid

The European Commission combines specific funds for women's empowerment with gender mainstreaming in its twin-track approach to gender equality in development aid policies. The strategy is successful in terms of budgets and formal appearance but it is implemented in a limited, interest-guided and expertbureaucratic manner. Furthermore by privi- leging EU interests the strategy fails to address the needs of the poorest developing countries and it ignores civil society concerns. In practice, the twin-track strategy severely limits the transformative potential of gender equality policies.

Petra Debusscher, PhD Postdoctoral researcjer, Special Research Fund University of Ghent 